\title{
KAJIAN EKONOMI USAHATANI KACANG TANAH (Arachis hypogaea L) DI KELURAHAN BAGAN PETE KECAMATAN ALAM BARAJO KOTA JAMBI
}

\author{
${ }^{1}$ Rogayah dan ${ }^{2}$ Evi Kurniati \\ ${ }^{1}$ Program Studi Agribisnisi Fakultas Pertanian Universitas Batanghari \\ ${ }^{2}$ Alumni Program Studi Agribisnis, Fakultas Pertanian Universitas Batanghari \\ Jl. Slamet Riyadi, Broni Jambi, 36122. Telp. +62741 60103 \\ ${ }^{1}$ Email Koresponden : rogayah_gayah@yahoo.com
}

\begin{abstract}
Bagan Pete Village, Alam Barajo Ditrict, JambiCity Is one of the centre ofpeanut farmingin Jambi City.However, the farmer never details count the costsand never calculates the amount of revenue in a single harvest period. The purpose of this study was to describe peanut farming activity and to analyze the peanut farming income. This Study used a survey method carried out in the Bagan Pete SubDistrict of Alam BarajoSubdistrict wherethe kelurahan was farmers whocultivated peanut.The number of samplestaken in this study were 35 farmer households or the entire populatian taken by census. The results of this study showed that theaverage total cost was $R p$ 1.589.505 /Period. Consisting of fixed costs of $R p$ 63.662/Peroid and variable costs of Rp. 1.525.989/ Peroid. The average revenue obtained by the farmers was Rp 4.498.000/Period,and average income of $R p$ 2.908.238/Period.
\end{abstract}

Keywords : Economic analysis, Farming, Peanut

\begin{abstract}
Abstrak
Kelurahan bagan pete Kecamatan Alam Barajo Kota Jambi merupakan salah satu sentra usahatani kacang tanah di Kota Jambi. Namun petani belum membuat perincian biaya-biaya yang dikeluarkan sertamenghitung jumlah penerimaan dalam satu kali musimtanam.Tujuan dari penelitian ini untuk menggambarkan kegiatanusahatani kacang tanah serta menganalisis pendapatan usahatani kacang tanahdengan menggunakan metode survay. Jumlah sampel sebanyak 35 rumah tangga petani(RTP) atau seluruh jumlah populasi yang ada dengan cara sensus.Hasil penelitian menunjukkan bahwa rata-rata total biaya adalah sebesar Rp1.589.505-,/Mt yang terdiri dari biaya tetap sebesar Rp63.662-,/Mt dan biaya tidak tetap sebesar Rp1.525.986-,/Mt. Rata-rata penerimaan yang diperoleh petani sebesar Rp 4.498.000-,/Mt dengan rata-rata pendapatan sebesar Rp 2.908.238,-/Mt
\end{abstract} Kata Kunci: Kajian Ekonomi, Usahatani, Kacang tanah

\section{PENDAHULUAN}

Provinsi Jambi merupakan salah satu Provinsi penghasil kacang tanah di Indonesia,dimana terdapat 11 Kabupaten/Kota yang melakukan usahatani kacang tanah.Dari 11 Kabupaten Kota tersebut Kota Jambi adalah penghasil kacang tanah dengan produktivitas lebih tinggi dari rata-rata produktivitas di Provinsi Jambi 
yaitu 1,74 (Dinas Tanaman Pangan,hortikultura dan peternakan Provinsi Jambi 2018). Kota Jambi Terdiri dari 11 Kecamatan, salah satunya Kecamatan Alam Barajo yang memiliki produktivitas tertinggi sebesar $2 \mathrm{Ton} / \mathrm{Ha}$ (Dinas Pertanian,Peternakan,Perikanan dan Kehutanan Kota Jambi 2018). Kecamatan Alam Barajo terdiri dari 5 Kelurahan,salah satunya kelurahan Bagan Pete adalah penghasil kacang tanah dengan luas panen terbesar bila dibandingkan dengan Kelurahan lain yang ada di Kecamatan Alam Barajo.Kelurahan Bagan Pete memiliki luas panen sebesar 6,75 Ha dengan produktivitas sebesar 2 Ton/Ha dan jumlah produksi 13,5 Ton (Balai Penyuluhan Pertanian dan Peternakan Kecamatan Alam Barajo Kota Jambi 2018).

Tanaman kacang tanah telah lama diusahakan petani di Kelurahan Bagan Pete .Tetapi yang terjadi dikalangan petani setelah tanamannya ber produksi jarang petani menghitung pendapatan usahataninya secara ekonomi Artinya mereka tidak pernah membuat perincian biaya-biaya yang dikeluarkan serta tidak pernah menghitung jumlah penerimaan sekali panen. Sehingga berapa keuntungan yang didapat dalam sekali panen hampir tidak diketahui. Hal ini disebabkan oleh keterbatasan petani itu sendiri. Besar kecilnya pendapatan dipengaruhi oleh penerimaan yang diperoleh petani dan biaya yang dikeluarkan oleh petani. Semakin besar pendapatan yang diperoleh petani maka semakin giat dan bersemangat petani tersebut melakukan usahataninya sehingga kehidupan petani tersebut sejahtera. Begitu juga sebaliknya,dengan harga kacang tanah yang cukup tinggi secara tidak langsung pendapatan petani juga bertambah.

Oleh karena itu, penelitian ini bertujuan untuk Menggambarkan kegiatanusahatani kacang tanah mulai dari hulu hingga hilir di Kelurahan Bagan pete Kecamatam Alam Barajo Kota Jambi dan Menganalisis pendapatan usahatani Kacang tanah

\section{METODOLOGI PENELITIAN}

Pelaksanaan penelitian ini dilakukan pada usahatani kacang tanah yang berada di Kelurahan Bagan pete Kecamatan Alam Barajo Kota Jambi. Dipilihnya daerah ini sebagai lokasi penelitian dengan pertimbangan bahwa daerah ini merupakan salah satu sentra produksi kacang tanah dengan luas panen sebesar yaitu $6,75 \mathrm{Ha}$ dan produksi sebesar 13,5 Ton, pengambilan data penelitian yaitu dilakukan pada bulam Maret-April 2019.Penelitian ini dibatasi pada kajian aspek gambaran kegiatan dan pendapatan. Adapunjenis data yang digunakan berdasarkan waktu adalah cross section, data cross section adalah data yang dikumpulkan dari suatu waktu tertentu pada beberapa objek dengan tujuan untuk menggambarkan keadaan.Jenis data menurut skala pengukuran adalah data Rasio. Sumber data yang digunakan dalam penelitian ini adalah data primer dan data sekunder, data primer adalah data yang diperoleh langsung dari masing-masing petani kacang tanah, sedangkan data sekunder adalah data yang diperoleh dari hasil publikasi, instansi terkait dan literature pustaka yang ada relevansinya dengan penelitian ini. Sedangkan metode yang digunakan dalam penelitian ini adalah metode survey,menurut Silalahi,U (2010) dalam Rahmat (2015) metode survey adalah suatu usaha untuk mendapatkan dan mengumpulkan data dan informasi dari berbagai sumber. Populasi petani yang mengusahakan usahatani 
kacang tanah berjumlah 35 orang yang diambil sebagai sampel dengan cara sensus.

Tasri,E.S.(2007) menyatakan bahwa sampel adalah kumpulan unit sampling yang merupakan subset dari populasi atau bagian tertentu yang terpilih dari populasi. Sampel dapat digunakan dalam penelitian untuk menghemat biaya,mempercepat pelaksanaan penelitian,menghemat tenaga,memperluas ruang lingkup penyajian dan memperoleh hasil yang lebih akurat. Selanjutnya sampel dapat digunakan apabila keadaan objek populasi homogen. Berdasarkan uraian tersebut maka digunakan sampel dalam penelitian ini adalah seluruh petani yang mengusahakan tanaman kacang tanah di Kelurahan Bagan Pete Kecamatan Alam Barajo yaitu sebesar 35 orang dengan tehnik pengambilan sampel secara sensus.

Data yang diperoleh dari hasil penelitian disederhanakan terlebih dahulu dengan cara tabulasi dan persentase (\%) atau dianalisis secara deskriptif baik kuantitatif maupun kualitatif untuk mengetahui gambaran usahatani kacang tanah, untuk mengetahui besarnya jumlah biaya produksi atau Total Cost (TC) adalah dengan menjumlahkan total biaya tetap atau total fixed cost (TFC) dan total biaya pariabel atau variable cost (TVC) dalam rupiah per musim tanam dengan menggunakan rumus Sudarman dan Algifari (2001) sebagai berikut:

$T C=T F C+T V C$

Dimana:

$\mathrm{TC}=$ Total biaya atau Total Cost $(\mathrm{Rp} / \mathrm{Mt})$

TFC $=$ Total Biaya Tetap atau Fixed Cost $(\mathrm{Rp} / \mathrm{Mt})$

$\mathrm{TVC}=$ Total Biaya variable atau Variabel cost $(\mathrm{Rp} / \mathrm{Mt})$

Untuk menghitung biaya tetap (TFC) penyusutan alat digunakan rumus metode garis lurus (Sudaraman dan Algifari,2001) sebagai berikut:

$\mathrm{D}=\frac{\mathrm{P}-\mathrm{S}}{N}$

Dimana:

$\mathrm{D}=$ Biaya penyusutan alat /musim tanam $(\mathrm{Rp} / \mathrm{Mt})$

$\mathrm{P}=$ Nilai awal alat $(\mathrm{Rp})$

$\mathrm{S}=$ Nilai akhir alat $(\mathrm{Rp} / \mathrm{Mt})$ dengan asumsi $=0$

$\mathrm{N}=$ Perkiraan umur ekonomis (musim tanam)

Untuk menghitung penerimaan ditentukan dengan menggunakan rumus Samuelson dan Nordhaus (2003) sebagai berikut :

$T R=P q x Q$

Dimana:

$\mathrm{TR}=$ Total penerimaan atau Totan Revenue $(\mathrm{Rp} / \mathrm{Mt})$

$\mathrm{Pq}=$ Harga produk $(\mathrm{Rp} / \mathrm{Kg})$

$\mathrm{Q}=$ Jumlah produksi $(\mathrm{Kg} / \mathrm{Mt})$ 
Untuk mengetahui pendapatan yang diperoleh dengan cara mengurangkan total penerimaan dengan total biaya, dengan menggunakan rumus Kasim (2006) sebagai berikut:

$I=T R-T C$

Dimana :

$\mathrm{I}=$ Pendapatan atau income $(\mathrm{Rp} / \mathrm{Mt})$

$\mathrm{TR}=$ Total penerimaan atau Total Revenue $(\mathrm{Rp} / \mathrm{Mt})$

$\mathrm{TC}=$ Total biaya atau Total Cost $(\mathrm{Rp} / \mathrm{Mt})$

\section{Identitas Responden}

\section{HASIL DAN PEMBAHASAN}

\section{Umur petani}

Umur adalah satuan waktu yang mengukur waktu keberadaan suatu benda atau makhluk,baik yang hidup maupun yang mati . Umur dapat mempengaruhi fisik dan kemampuan berfikir seorang petani. Petani muda yang sehat mempunyai kemampuan fisik untuk bekerja dari pada petani tua,petani muda juga pada umumnya lebih cepat menerima hal baru dari pada petani yang berusia lebih lanjut. Karena mereka lebih berani menanggung risiko,karena mereka kurang memiliki pengalaman sehingga petani muda harus lebih dinamis agar mendapatkan pengalaman baru lebih cepat untuk usahataninya. Dari hasil penelitian terhadap 35 orang petani diperoleh umur petani berkisar antara 32 sampai 80 tahun dengan rata-rata 53 tahun sedangkan mayoritas umur petani berada pada kisaran 41 - 49 tahun dengan persentase $29 \%$ dari angka ini dapat disimpulkan bahwa umur petani yang mengusahakan tanaman kacang tanah di daerah penelitian sebagian besar tergolong produktif, sejalan dengan pendapat Tuwo (2001) penduduk yang tergolong usia kerja adalah berusia 15-50 tahun. Dengan kondisi petani yang rata-rata berumur produktif maka diharapkan mampu mengolah usahataninya secara maksimal dengan tujuan untuk meningkatkan produksi yang optimal.

\section{Pendidikan Petani}

Pendidikan mampu membentuk kepribadian,melalui pendidikan lingkungan baik yang disengaja maupun yang tidak disengaja. Pendidikan yang tinggi mampu meningkatkan wawasan,keahlian, status dan harapan seseorang dalam menerima perubahan-perubahandalam perkembangan ilmu pengetahuan dan perkembangan tehnologi. Jika petani memiliki kemampuan membaca berbagai tulisan yang berhubungan dengan usahatani seperti teknologi baru,perubahan harga dan cara pemasaran yang lebih efisien. Dari hasil penelitian terhadap 35 orang petani terlihat bahwa sebagian besar atau $49 \%$ petani berpendidikan SMA, dengan pendidikan yang dimiliki petani tersebut diharapkan dapat mengikuti perkembangan teknologi dalam kegiatan usahatani yang dijalankan

\section{Jumlah Tanggungan Keluarga}

Keluarga adalah kumpulan dua orang atau lebih yang mempunyai hubungan darah,perkawinan,kelahiran dan adopsi yang bertujuan untuk menciptakan, mempertahankan budaya dan meningkatkan perkembangan fisik,mental emosional serta sosial dari setiap anggota keluarga (Logan.D,1989). Jumlah

Diterbitkan oleh Program Studi Agribisnis Fakultas Pertanian Universitas Batanghari Jambi Halaman 71 
anggota keluarga sangat berhubungan dengan jumlah kebutuhan keluarga. Semakin banyak jumlah anggota keluarga berarti semakin banyak pula jumlah kebutuhan yang harus dipenuhi, semakin sedikit jumlah anggota keluarga berarti semakin sedikit pula jumlah kebutuhan keluarga yang harus dipenuhi, dari hasil penelitian memperlihatkan bahwa $43 \%$ dari petani sampel mempunyai jumlah anggota keluarga sebanyak 3 orang, Sedangkan rata-rata jumlah anggota keluarga sebanyak 4 orang.

Banyaknya jumlah anggota keluarga merupakan potensi yang dapat dimanfaatkan oleh petani sebagai tenaga kerja dari dalam keluarga sehingga dapat meringankan biaya upah tenaga kerja yang dikeluarkan dalam kegiatan usahatani.

\section{Luas Lahan Petani}

Luas lahan merupakan penentu dalam menghasilkan produksi pertanian, secara umum dikatakan semakin luas lahan yang diusahakan maka semakin besar jumlah produksi yang akan dihasilkan.Luas penggunaan lahan petani yaitu berkisar antara $250-1.875 \mathrm{~m}^{2}(83 \%)$ dengan rata-rata seluas $1.389 \mathrm{~m}^{2}$

\section{Gambaran Kegiatan Usahatani Kacang Tanah}

Usahatani kacang tanah telah lama diusahakan petani sehingga petani cukup memahami apa saja yang harus dilakukan terlebih dahulu sebelum penanaman seperti menyiapkan keperluan untuk kegiatan yaitu cangkul,parang,sabit,hand sprayer,karung untuk kacang tanah setelah panen dan semua ini diperoleh petani dengan cara membeli di toko pertanian yang ada didekat pusat produksi.

Bibit yang digunakan petani Varietas bibit lokal,menggunakan pupuk kandang,NPK dan pestisida (amistartop) yang diperlukan untuk memberantas penyakit bercak daun dan busuk daun sedangkan obat yang dipakai untuk gulma yaitu gramaxon,untuk memberantas kutu loncat digunakan obat kutu loncat,kutu daun,ulat,semut,rayap sedangkan untuk virus dan jamur digunakan nopatek,semua ini disiapkan oleh petani sebelum melakukan penanaman nsehingga begitu diperlukan petani tinggal menggunakan.

Pembersihan lahan dilakukan dengan mencangkul rata agar gembur, diberi pupuk kandang kemudian dibiarkan selama 4-7 hari kemudian baru dilakukan penanaman dengan cara ditugal dan menggunakan kayu dengan jarak tanam 20 $\mathrm{x} 40 \mathrm{~cm}$ dan dimasukkan 1 butir biji kacang per lubang,penanaman dilakukan biasanya di pagi atau sore hari. Setelah tanaman berumur 25 hari atau bunga pertama muncul maka petani mulai melakukan pembumbunan agar kacang berbuah banyak dan setelah berumur 105-110 hari kacang tanah sudah siap untuk dipanen atau terkadang pada daun kacang terlihat warnanya berubah menjadi hijau kekuningan dan timbul bintik-bintik seperti karat. Kacang tanah yang sudah siap dipanen dicabut dari tanah kemudian dilepaskan dari akarnya dan biji-biji kacang dibersihkan dari tanah yang menempel, kemudian dijemur sebentar untuk sekedar mengeringkan kulit luarnya agar memiliki daya simpan yang lebih lama selanjutnya kacang dimasukkan kedalam karung dan dibawak kerumah,rata-rata produksi sebanyak $346 \mathrm{~kg} /$ Mt.Proses pemasaran kacang ini petani cukup menunggu pembeli datang kerumah,sehingga petani tidak mengeluarkan biaya trasportani dengan harga rata-rata $\mathrm{Rp} 13.000,-/ \mathrm{kg}$ 


\section{Biaya Produksi Usahatani Kacang Tanah}

Biaya produksi kacang tanah yang dihitung adalah biaya tetap yang berasal dari penggunaan alat yaitu penyusutan alat berdasarkan umur ekonomis alat seperti cangkul,parang,sabit,karung dan hand sprayer,sedangkan untuk biaya tidak tetap berupa benih,pupuk kandang,pupuk NPK dan obat-obatan seperti pada tabel berikut:

Tabel 1.Rata-rata Jumlah Komponen Biaya Produksi Usahatani Kacang tanah

\begin{tabular}{clcc}
\hline No & Uraian Komponen Biaya & Jumlah $(\mathrm{Rp} / \mathrm{Mt})$ & Persentase $(\%)$ \\
\hline 1. & Biaya Tetap & 63.663 & 4 \\
& 1. Cangkul & 14.011 & 0,9 \\
2. Hand Sprayer & 32.143 & 2 \\
3. Parang & 5.897 & 0,3 \\
4. Sabit & 5.714 & 0,3 \\
5. Karung & 5.897 & 0,3 \\
2. Biaya Tidak Tetap & 1.525 .986 & 96 \\
1. Pupuk Kandang & 30.286 & 1,9 \\
2. Pupuk NPK & 1.195 .200 & 75,2 \\
3. Obat-obatan & 79.243 & 5 \\
4. Benih & 221.257 & 14 \\
Jumlah (Total Biaya) & 1.589 .505 & 100 \\
\hline
\end{tabular}

Sumber: Data primer yang diolah.

Dari tabel diatas dapat dilihat rata-rata penggunaan biaya tetap terbesar adalah pada penggunaan alat Hand Sprayer dengan persentase $2 \%$ terkecil adalah alat parang,sabit dan karung yaitu $0,3 \%$ sedangkan penggunaan biaya tidak tetap terbesar adalah pada penggunaan pupuk NPK yaitu sebesar 75,2 \% dan terkecil adalah pada penggunaan pupuk kandang yaitu sebesar 1,9\%

\section{Penerimaan Usahatani}

Penerimaan yang diperoleh petani adalah yang didapat dari hasil perkalian antara jumlah produksi dengan harga jual per kg seperti terdapat pada Tabel 2 berikut ini.

Tabel 2. Rata-rata Penerimaan Usahatani Kacang Tanah

\begin{tabular}{cc}
\hline Uraian & Jumlah \\
\hline Total Produksi & $346 \mathrm{Kg} / \mathrm{Mt}$ \\
Harga & Rp. $13.000 / \mathrm{Kg}$ \\
\hline Penerimaan & Rp. $4.498 .000 / \mathrm{Mt}$ \\
\hline
\end{tabular}

Sumber:Data primer yang diolah

Besar kecilnya penerimaan yang diperoleh petani dipengaruhi langsung oleh jumlah produksi yang dihasilkan dan harga yang berlaku pada saat penjualan, oleh karena itu petani harus mengetahui saat yang tepat untuk melakukan transaksi penjualan karena penggunaan kacang tanah tidak selalu diperlukan dengan jumlah 
yang banyak kecuali pada saat-saat tertentu seperti pada waktu lebaran idul fitri,selain dari itu kacang tanah sebenarnya bisa disimpan dalam waktu yang cukup lama asalkan petani mau melakukan penjemuran hingga kering dan mengupasnya dan ini akan diperoleh harga jual yang cukup tinggi walaupun dari jumlah terjadi penyusutan.

\section{Pendapatan Usahatani Kacang Tanah}

Pendapatan yang diperoleh petani merupakan selisih antara penerimaan dengan semua biaya produksi yang dikeluarkan dalam proses produksi, untuk lebih jelasnya dapat dilihat pada Tabel 3 berikut ini:

Tabel 3. Rata-rata Pendapatan Usahatani Kacang Tanah

\begin{tabular}{cc}
\hline Uraian & Jumlah $(\mathrm{Rp} / \mathrm{Mt})$ \\
\hline Total penerimaan & 4.498 .000 \\
Total biaya & 1.589 .694 \\
Pendapatan & 2.908 .351 \\
\hline
\end{tabular}

Sumber : Data primer yang diolah

Dari tabel diatas terlihat bahwa dengan rata-rata luas lahan $1.389 \mathrm{~m} 2$ petani sudah memperoleh pendapatan sebesar Rp2.908.351,-/Mt dan jika kita melihat jumlah penerimaan yang diperoleh petani jauh lebih besar dari biaya yang dikeluarkan hal ini berarti penerimaan petani bisa menutupi seluruh biaya yang dikeluarkan dalam proses produksi usahatani yang dijalankan,tetapi bila dilihat dari pendapatan per bulan dengan periode musim tanam selama4 bulan maka jumlah pendapatan yang diperoleh adalah sebesar $\mathrm{Rp} 727.087,7,-/$ bulan,jika dibandingkan dengan upah minimum regional (UMR) sebesar Rp 2.423.889/bulan (Disnakertrans Provinsi Jambi,2018) maka nilai tersebut masih dibawah UMR.

\section{KESIMPULAN}

Dari hasil yang diperoleh dalam penelitian di daerah Kelurahan Bagan Pete Kecamatan Alam Barajo dapat disimpulkan sebagai berikut:

1. Luas lahan yang ditanami petani rata-rata $1.389 \mathrm{~m}^{2}$ atau 0,139 Ha. Jarak tanam kacang tanah $20 \times 40 \mathrm{~cm}$,menggunakan pupuk kandang dengan frekuensi pemberian satu kali / musim tanam,pupuk NPK dengan frekuensi pemberian dua kali / musim tanam pemakaian obat-obatan satu kali/musim tanam, menggunakan tenaga kerja dari dalam keluarga. Pemanenen dilakukan setelah kacang tanah berumur 105-110 hari,rata-rata produksi sebesar $346 \mathrm{~kg} / \mathrm{Mt}$

2. Rata-rata total biaya produksi sebesar Rp 1.589.649,-/Mt yang terdiri dari biaya tetap sebesar Rp 63.663,-/Mt dan biaya variable sebesar Rp 1.525.986,/Mt.Rata-rata penerimaan yang diperoleh sebesar Rp 4.498.000,-/Mt dan ratarata pendapatan sebesar Rp 2.908.351,-/Mt

\section{DAFTAR PUSTAKA}

Balai Penyuluhan Pertanian,Perikanan dan Peternakan Kecamatan Alam Barajo Kota Jambi 2018. Luas Panen dan Produksi Kacang Tanah Menurut Kelurahan di Kecamatan Alam Berajo tahun 2017. Jambi 
Dinas Pertanian, Peternakan dan Kehutanan 2018.Luas Panen dan Produksi Kacang Tanah Menurut Kecamatan di Kota Jambi Tahun 2017. Jambi

Dinas Tenaga Kerja dan Transmigrasi. 2018.Upah Minimum Regional Provinsi Jambi

Dinas Tanaman Pangan Hortikultura dan Peternakan.2018. Luas Panen dan Produksi Kacang Tanah Menurut Kabupaten/Kota di Provinsi Jambi tahun 2017. Jambi.

Duvall dan Logan. 1986.Marriage and Family Development Harper and Row Publisher. NewYork

Kasim.2006. Karakteristik Kemiskinan di Indonesia dan Strategi Penanggulangannya. Studi Kasus: Padang Pariaman.Indonesia. Jakarta.

Samueljan dan Nordhus.2003. Ilmu Makro Ekonomi. PT Media Global Edukasi. Jakarta

Silalahi,U.2010. Metode Penelitian Sosial.Refika Aditama. Bandung.

Sudarman dan Algifari. 2001. Ekomoni Mikro - Makro. Fakultas Ekonomi. Universitas Gajah Mada. Yokyakarta

Tasri E,S.2007.Metode Penelitian Ekonomi dan Basisi. Bung Hatta University Press. Padang

Tuwo, M. Akib.2011. Ilmu Usahatani Tiori dan Aplikasi Menuju Sukses.Udhalu Press. Kandari 